\title{
The Mechanisms of Implementing the Strategy for Regional Socioeconomic Development in the Context of Public Network Management*
}

\author{
Tatyana Myasnikova \\ Faculty of Management and Psychology \\ Department of State and Municipal Administration \\ Kuban State University \\ Krasnodar, Russia \\ E-mail: ormx@mail.ru \\ Tatyana Kolmykova \\ Department of Banking and Finance \\ Southwest State University \\ Kursk, Russia \\ E-mail: t_kolmykova@mail.ru
}

\author{
Konstantin Getmantsev \\ Faculty of Management and Psychology \\ Department of Organization and Planning of Local \\ Development \\ Kuban State University \\ Krasnodar, Russia \\ E-mail: kot34@mail.ru
}

Svetlana Lobanova

Faculty of Management and Psychology

Department of Social Work, Pedagogics and Psychology of the Higher Education, Kuban State University

Krasnodar, Russia

E-mail: lobanovasw@mail.ru

\begin{abstract}
The present article studies the issues of managing the socio-economic development strategies of Russian regions. The authors present the findings of the research on 24 development strategies and other strategic documents of the constituent entities of the Russian Federation and propose recommendations on improving the mechanisms and tools of implementing regional strategies.
\end{abstract}

Keywords - regional development strategy; network public management; regional community; stakeholder; organization and management mechanism; socioeconomic development; transformation; local community; social network; collaborative management; horizontally integrated management networks; change management

\section{INTRODUCTION}

The practice of state and local government in the Russian Federation has been exercising strategic planning for several decades. Russian methodology and technology of strategic planning have their special features, but may well be valuable to analyse and further introduce into the world practice of spatial development. The current stage of the development of strategic spatial planning methodology is characterized by concepts transformation: decomposition of development goals and objectives, enhancements to the development management system, and the search for new mechanisms for implementing development tools. The principle drawback of the Russian regions' development

*Fund: The study was carried out with financial support from the Russian Foundation for Basic Research in the framework of the scientific project No. 18-410-230026 p a "The model of public network management of the strategy for socio-economic development of Krasnodar Krai”. strategies is the insufficient instruments for their implementation. The problem may be overcome by introducing the model of public network strategy management, which presupposes creating vertically and horizontally integrated management systems based on the principles of participativity and subsidiarity.

\section{THE CONCEPT OF RESEARCH}

Strategic planning is widely applied in current management practice of Russian regions. The following four stages describe the development of the strategic spatial planning methodology in Russia:

1990s - 2005: At this stage, the methodology for the strategic planning of spatial development in the conditions of market economy was formed (S. Glazyev, A. Granberg, B. Kuzyk, V. Leksin, A. Shvetsov). This stage was characterized by the introduction of the USA and European experience in strategic planning, the availability of a variety of approaches and the absence if the unified regulatory framework. During this period, the strategies for socioeconomic development or other long-term strategic plans were developed in practically all regions of Russia: in over 200 Russian cities (75 of them - small towns) and in individual rural regions. [1]

2005 - 2014: During the second stage, the unified methodology and regulatory framework for strategic planning was being shaped in the Russian Federation. In October 2005, at the instruction of the Prime Minister of the Russian Federation, the Ministry of Economic Development of Russia organized works upon the strategies for the socio- 
development strategy of the region as a social contract of the regional community; regional stakeholders and local governments are also becoming the subjects of regional development management;

- the abandonment of administrative methods of influencing the economy, using soft economic regulation methods;

- digitalization of management processes, ensuring strategy flexibility, attracting a network society to managing the strategy using modern technologies;

- the emphasis on mechanisms and tools for implementing development strategies, the search for innovative instruments.

The methodological approach to assessing the strategies for regional socio-economic development has been designed by the authors. It includes the criteria and the algorithm for strategy evaluation and provides two assessment methods: analysing strategic planning documents and information environments, and the method of expert evaluations (surveys in focus groups).

The algorithm for strategy assessment consists of the following steps:

- analysing the institutional preconditions and the planning model;

- analysing the Strategy for socio-economic development (its compliance with the principles of strategic planning, the quality of the consideration of individual issues, the representativity of the strategic doctrine);

- analysing the documents regulating the implementation of the regional development strategy.

The results of the performed analysis are to be arranged in tabular and graphical forms.

\section{EXPERIENCE OF RUSSIAN REGIONS}

In the research, the authors analysed strategies and strategic documents on socio-economic development of 24 Russian regions, including Arkhangelsk Oblast, Moscow Oblast, Krasnodar Krai, Stavropol Krai and others.

When analysing the strategic documents of the abovementioned regions, the focus was on three aspects:

- the model of the subject of strategy management (monocentric or network) and the engagement of the regional community in strategy management;

- digitalization of the processes of strategy development and implementation, and the availability of interactive electronic platforms that enable online interaction between the participants of the planning process;

- the mechanisms and tools for strategy implementation.

- the subject of regional development management is transforming: there is a growing perception of the 
- organization and management mechanism, which implies creating institutional conditions for strategy implementation and a strategy management system (identifying the subject of management, its functionality), designing a set of programs and projects for strategy implementation (implementation plan, monitoring plan, etc.);

- legal mechanism, which implies legitimizing strategic documents through formal procedures;

Second, the conception of the subject of regional development strategic management is transforming. Regional authorities engage regional stakeholders in the planning process and implement the principles of collaborative management. Public hearings for strategies have been conducted, with the participation of civil society and business community representatives. For instance, the Strategy for Samara Oblast socio-economic development until 2030 was collaboratively developed by the Ministry of Economic Development, Investments and Trade of Samara Oblast and CJSC Strategy Partners Group with the participation of municipal entities authorities, the representatives of large, small and medium-sized businesses, universities, the public [5]. Thus, local government participation enables building a vertically integrated management network, while the participation of local communities contributes to developing a horizontally integrated management network when implementing the development strategy.

Third, digital technologies were applied when developing all regional development strategies under analysis. To ensure the development and discussion of some of them, special Internet environment was created, for instance, the Strategic Portal of Krasnodar Krai (within the development of the Kuban-2030 Strategy), which contains [6]:

- the description of the original methodology for developing a "live" development strategy for Krasnodar Krai based on the "Galaxy AV Dynamic System of Future Management" - the theory of interregional and global competition and spatial development;

- the description of economic zones and complexes of the region;

- $\quad$ strategic directions of regional development (7 areas of competitiveness: markets, institutions, human capital, innovation and information, natural resources and sustainable development, territory and real capital, investment and financial capital);

- project sites;

- interactive sites (forums) on three areas: competitiveness, economic and social development, and spatial development. Discussions can take place in social networks (e.g. https://www.facebook.com, https://vk.com/kuban30).

In order to implement regional development strategies effectively, the following mechanisms are available:
- economic and financial mechanism, which implies attracting budgetary and extra-budgetary funds, private investment resources, and implementing public private partnership projects.

Almost no strategy describes the social mechanism for regional development strategy implementation, providing instruments for managing social changes the strategies will result in.

In the present research, the authors have analysed the instruments for the implementation of Russian regions' development strategies, including:

- traditional: state programs, measures provided by state policy, spatial planning schemes, monitoring systems (in $100 \%$ of strategies under analysis);

- market: investment projects, public private partnership projects (in 97\% of strategies under analysis);

- innovative: change management, place marketing, communication platform (in $50 \%$ of strategies under analysis).

The Russian experience of strategic planning at the regional level is generally positive; nevertheless, there are a number of challenges to highlight:

- the engagement of the regional community in shaping and implementing development strategies is often a formality;

- strategic documentation does not contain the description of social mechanism for implementing regional development strategies;

- such tools as plans of place marketing, change management projects and public private partnership projects are not applied;

- the system of strategy implementation management is fragmented.

\section{RECOMMENDATIONS}

To enhance the methodology and practice of strategic management of regional socio-economic development, the authors propose implementing the model of public network strategy management based on leading scientific schools and concepts:

- $\quad$ strategizing spatial development [2]; 
strategic planning. In general, taking into account the improved quality of strategic documentation at the regional level, there are still some points of weakness: the engagement of the regional community in shaping and implementing development strategies is often a formality; social mechanisms of strategy implementation and such tools as plans of place marketing and change management projects are not applied; strategy implementation management is fragmented.

To minimize these weaknesses, the authors propose implementing the model of public network management of the regional socio-economic development strategy. It implies building vertically and horizontally integrated management systems according to the principles of participativity and subsidiarity and expanding the available instruments for strategy management by means of developing social management mechanisms.

\section{REFERENCES}

[1] Strategic planning in Russian cities. Review on the results of quality of strategic planning assessment in 20 cities / B.S. Zhikharevich, N.B. Zhunda, I.A. Korelina, L.E. Limonov, O.V. Rusetskaya, et al. St. Petersburg, 2002. 26 p.

[2] Myasnikova T.A. Theoretical provisions and methodological support of strategizing socio-economic development of municipalities in Russian regions: $\mathrm{PhD}$ dissertation. Voronezh: Voronezh State University, $2016.374 \mathrm{p}$.

[3] “On Strategic Planning in the Russian Federation", Federal Law 172 FZ, dated June 28, 2014 // Rossiyskaya Gazeta. Available at: http://www.rg.ru/2014/07/03/strategia-dok.html

[4] Strategies for Arkhangelsk Oblast socio-economic development until 2035. Available

at: http://economy.gov.ru/wps/wcm/connect/49109151-6955-4749-b347$213 \mathrm{db} 5 \mathrm{c} 33 \mathrm{eb} 6 / \mathrm{stratega} . \mathrm{pdf}$ ?MOD=AJPERES\&CACHEID $=49109151$ -6955-4749-b347-213db5c33eb6

[5] Strategy for Samara Oblast socio-economic development until 2030 Available

https://economy.samregion.ru/upload/iblock/82a/strategiyaso_2030.pdf

[6] Strategic Portal of Krasnodar Krai. Available at: http://kuban.lc-av.ru/

[7] Filippov Yu.V. The basics of local economy development: study guide / Yu.V. Filippov, T.A. Avdeeva. 2nd ed. Moscow: Logos. 2011 $276 \mathrm{p}$.

[8] Voblenko S.V. Introduction to -collaborative managementl/ S.V. Voblenko, P.R. Korsby, A.V. Usenkov. Moscow: Veche. 2004, 150 p

[9] Getmantsev K.V., Lanskaya D.V., Myasnikova T.A., Treshevsky Y.I. The Current Practice of the Strategic Planning in Russian Regions: Innovative Model of Strategic Planning "Galaxy $7 \times 7 \times 7$ " of the Leontief Centre-AV Group Consortium and Experience of Its Approbation in Krasnodar Krai// The Future of the Global Financial System: Downfall or Harmony: International Conference Project, Vol 57 Springer Nature Switzerland AG 2019 Cham, 2018. P. 105-113

[10] Myasnikova T.A. Overcoming the target groups resistance during organizational changes // Change management in socio-economic systems: collection of articles of the 11th international research and practice conference / ed. by V.P. Bocharova, I.E. Risina, Yu.I. Treschevsky. Voronezh State University. Voronezh. 2012. Iss. 11. V. 1. Pp. 107-122.

In the article, the authors analysed the experience of strategic planning of socio-economic development in Russian regions. The adoption of the Federal Law 172-FZ "On strategic planning in the Russian Federation" has resulted in changes to the methodology and technology of 